\title{
Chemical and Nutrient Evaluation of Moringa Oleifera Seed and Oil Cultivated in Egypt
}

\author{
Mahmud, G. F. ${ }^{1}$; El Ghadban, E.A.E ${ }^{2}$ and Shahat, M. S. ${ }^{3}$
}

${ }^{1}$ Functional Foods Department, National Institute of Nutrition Canada, Ottawa. 2. Medicinal and Aromatic Plants Department, Horticultural Research Institute (H.R.I) ARC; National Gene Bank (N.G.B.).

3. Food Science and Technology Department , faculty of Agriculture, Al Azhar university, Cairo ,Egypt

ABSTRACT

his study was conducted on the extraction of oil from the plant Moringa
oleifera cultivated under Egyptian conditions in three places, is the
North Sinai Governorate (NS), Ismailia (IS), Minya (MA province). The aim was to study and evaluate effective nutritive value in the extracted seed oils Moringa oleifera, chemical and physical study of those components, $20 \mathrm{~kg}$ of ripe seeds were collected from three places (SN), (IS), (MA) and oil extraction, store at $-20^{\circ} \mathrm{C}$ until used. The results proved to contain Moringa oleifera seed to $40.2 \%$ by weight in favor of oils for human use next to contain nutrients granted retain vitality and viability of storage for a long time. The values (iodine - refractive index - saponification value - the values of density viscosity) do not have difference in the three sites under study. The values free fatty acids (FFA), show good resistance to oil degradation compared to the values of olive oil, corn oil, cotton oil, peanut oil. The values of peroxide with low values indicating a resistance to oil, Moringa oleifera from oxidation during storage, making it the important nutritional oils to store and persistence chemically, study proved that tocopherol values $(\alpha-\gamma-\delta$-) and the image of high values, was tocopherol - $\alpha$ (126.1-127) milligrams, so it has a greater vitamin (E) well compared to other oils such as coconut $17 \mathrm{mg}$, sunflower $7 \mathrm{mg}$. The fatty acids (FA) in Moringa oleifera oils containing oleic acid (C18: 1) up to $74.4 \%$ and is considered the best by comparing other. The presence of betasitosterol ( $\beta$-sitosterol) one of the important and which play an important role in the metabolism within the body and is an important and active ingredient for patients with high cholesterol and triglycerides and diseases of atherosclerosis and heart disease, obesity, food Sterols.

Keywords: Moringa oleifera, Moringa oil, Moringa oleifera chemical properties, seed oil 


\section{INTRODUCTION}

The Moringa oleifera genus is a common member of the family Moringaceae, which contains a wide range of plants, including flowering herbs and trees. It is commonly known as Horseradish tree, Benzolive, Kelor or Drumstick tree. The drumstick-like shape, curved seed pods is the characteristic for this species calling Drumstick tree (Asres, 1995). The origin tree is in Himalayas, India and it grows in tropical and semi-arid climates. Moringa tree reaches to about ten meters in height and is drought tolerant allowing it to thrive in arid climates. Moringa trees has multi-uses, as may be used food or medicinal plant, and each part of the tree may be utilized to benefit humans and provide other valuable materials for farming and fuel (Dahot, 1998).

The pods and leaves of Moringa trees were used for food in numerous cultures throughout the world. According to Bharali et al. (2003), it cultivated first in Northern India and incorporated into a number of religious and cultural observances. Derived-oils from the seeds were used as food and in unguents by the ancient Greeks, Romans and Egyptians and were part of the Ayurvedic health diet in India (Badgett, 1964).

The increasing interest of Moringa uses all over the world has led to its cultivation in many regions as well as the West India. The leaves, flowers and pods provide a number of necessary nutrients, including protein, beta-carotene, calcium and Vitamin C (Bharali et al., 2003). It is well good to use it (for humans or animals nutrition) in the poor regions in over the world, including Asia and Africa, making it more useful for fighting malnutrition of regions (D.Souza and Kulkarni, 1993).

Vlahov et al. (2002) and Abdulkarim et al. (2005) said that all parts of the Moringa tree-leaves, flowers, fruits, and roots are edible and have long been consumed as vegetables (Anwar and Bhanger 2003; Siddhuraju and Becker 2003). Moringa seed oil, also known as Ben oil, has been used in salads, 
for industry as fine machine lubrication, and in the manufacture of perfume and hair care products (Tsaknis et al. 1999). In Africa and some parts of Asia, particularly India, the oil has been used for cooking purposes (Dahot and Memon 1985; Dietz et al. 1994).

In recent years, considering the gap between demand and production of vegetable oils in many developing countries (Dietz et al. 1994), research focusing on the use of unconventional oilseeds as a source of vegetable oils has become important. There are some reports on the composition and characteristics of M. oleifera seed oil varieties from different countries of origin e.g.: India (Lalas and Tsaknis 2002), Kenya (Tsaknis et al. 1999), Malawi (Tsaknis et al. 1998), Pakistan (Anwar and Bhanger 2003; and Malaysia (Abdulkarim et al. 2005) Anwar et al. 2005; Anwar et al. 2006; Anwar and Rashid 2007) considering its prospect as an alternative vegetable oil source

\section{MATERIALS and METHODS}

This investigation was be carried out at medicinal and aromatic plants Department Horticulture Research Institute Agricultural Research Center Dokki, during the seasons 2014.

\section{Source of Moringa oleifera seeds}

Samples of Moringa oleifera seeds were obtained from three places in Egypt season 2014, as follows:

1. Sheikh Zuid Station, North Sinai Governorate - Center for Desert Research (NS)

2. Forest Sarabium, area (Sarabum), (Ismailia Governorate) - Ministry of Agriculture (IS)

3. (Beni Mazar) Minya Governorate (MA)

The mature pods of Moringa oleifera were collected to obtain approximately $20 \mathrm{~kg}$ of seeds from drumstick cultivation in the places under study. The seeds were removed from the pods, sorted, sun-dried and stored at -20C until further use. 
All chemicals used were of analytical of HPLC grade from Merck (Darmstadt, Germany) or Sigma-Aldrich (St. Louis, MO, USA). Standards of sterols, tocopherols and fatty methyl esters were obtained from Fluka Chemie (Buchs, Switzerland) and Sigma Chemical Co. (St. Louis, MO, USA).

The oil from the moringa seeds has been extracted using solvent extraction technique as described in AOCS (1998). The hexane used as solvent was recovered by Rotary Evaporator (Eyela, Japan). The extracted oil was stored in dark place at room temperature. Oil has been analyzed for physical \& chemical characteristics and fatty acid profile using their respective methodologies as presented Acid value is defined as the milligrams of $\mathrm{KOH}$ required for neutralization of free fatty acids present in one gram oil. Neutral alcohol was been added to moringa fixed oil sample and titrated against $\mathrm{KOH}$ solution (AOCS, 1998).

The moisture and protein content of seed residues, after the oil extraction, were determined using the methods described by Pearson et al. (1987), while determination of ash and crude fiber contents was done according to Pomeranz and Meloan (1994).

Standard methods were followed to measure different physical and chemical parameters such as density, refractive index, acidity, saponification value, iodine value, unsaponifiable matter (USM) (AOCS 1998) and viscosity of the different solventextracted variants of $\mathrm{M}$. oleifera seed oil. Colour was measured with a Lovibond tintometer (The Tintometer Ltd., Salisbury, England).

The oxidative state of the seed oil was determined by measuring peroxide value and specific extinctions at 232 and $270 \mathrm{~nm}$. The method suggested by AOCS (1998) was adopted for the measurement of peroxide value and the specific extinctions were determined with a spectrophotometer (U2001, Hitachi Instruments Inc., Tokyo, Japan) using the IUPAC (1987) method. Susceptibility to oxidation (Rancimat method) was determined using the 
method described by Tsaknis et al. (1998).

Tocopherol $(\alpha, \gamma$ and $\delta)$ analysis was performed using an HPLC system consisting of a L6000 Merck-Hitachi high pressure pump connected to an L-4000 Merck-Hitachi UV detector (Hitachi Instruments Inc., Tokyo, Japan) set at 295 $\mathrm{nm}$. Tocopherol contents were identified by comparing the retention times with those of pure standards as described by others (Anwar and Rashid 2007). A D-2500 Chromato Integrator (Merck, Darmstadt, Germany) was used for data acquisition and processing.

The AOAC (1990) method was used for the determination of sterols using a Shimadzu GC 17A Gas Chromatograph with FID Detector (Shimadzu Corporation, Kyoto, Japan). Sterols were identified and quantified by comparing the retention times and peak areas of the unknown components with those of a known sterol standard mixture.

Iodine Value is the number of grams of Iodine that combines with $100 \mathrm{~g}$ of oil or fat.
Iodine Value of an oil or fat indicates the amount of unsaturated fatty acids present in it. In practice, the given oil dissolved in carbon tetrachloride and then treated with iodine monochloride solution; the unused Iodine has been determined by titration against standard sodium thiosulphate (hypo) solution. An Iodine solution is violet in color and any chemical group in the substance that reacts with iodine come the color to disappear at a precise concentration. The amount of Iodine solution thus required to keep the solution violet is a measure of the amount of Iodine sensitive groups (AOAC, 1998).

Peroxide value (one of the most widely used tests for oxidative rancidity) is a measure of the concentration of peroxides and hydro peroxides formed in the initial stages of lipid oxidation. Milli-equivalent per kilogram peroxide of fat was measured by titration with iodide ion.

Fatty acid methyl esters, as converted from the corresponding fatty acids in the seed oil according to the IUPAC 
(1987) method, were analyzed by Philips Pye Unicam PU 4500 (Philips Electronics UK Ltd, Guildford, Surrey, UK) gas chromatography equipped with a flame ionization detector. The column (internal diameter $2 \mathrm{~mm}$, length $1.5 \mathrm{~m}$ ) (Philips Scientific, Cambridge, UK) was filled with $10 \%$ diethyl glycol succinate on a 100 to 200- (British standard sieve) mesh (Mallinckrodt Chemical Works, St. Louis, MO). Injection and detector temperatures were 230 and 250C, respectively. The column temperature was increased from 100 to $225 \mathrm{C}$, with a temperature increase gradient of 4C min-1. Nitrogen gas was used as the carrier gas at a flow rate of 11.3 $\mathrm{mL}$ min-1. The chromatograms were recorded with Spectra Pycis 4290 integrator (Spectra Physics, Irvine, CA). The amount of each fatty acid was given as a percentage of the total fatty acid content.

\section{Statistical Analysis}

Obtained data of this study were tabulated and statistically analyzed using randomized complete block design according to Snedecor and Cochran, 1967.

\section{RESULTS and DISCUSSION}

Attributable to the variety of plant, environmental and geological conditions of the regions and the extraction methods used (Ibrahim et al. 1974). The solvent-extracted oil yield $(37.5-40.2 \%)$ for $M$. oleifera seeds in the present analysis was found to exceed those of four conventional oilseed crops: cotton (15.0$24.0 \%$ ), soybean (17.0-21.0\%), safflower $\quad(25.0-40.0 \%)$, and mustard $(24.0-40.0 \%)$

\section{(Pritchard 1991)}

Proximate analysis of Moringa oleifera, oilseed residues reveals the protein, moisture, fiber, and ash contents in (Table 1). The protein content is high enough to be used as a fertilizer and as a potential animal foodstuff (Manzoor et al. 2007). Oilseed residues of $M$. oleifera can also be used as water-purifying agents (Anwar et al. 2005; Bhuptawat et al. 2007).

Various physical and chemical characteristics of the 
Moringa oleifera oils are presented in Table 2. The density and viscosity and other, here is no difference in the values resulting from the three sites ( (NS), (IS) and (MA) ) significant no impact on the following properties: refractive index (RI), color index, saponification value (SV) and iodine value (IV). Values of density, RI, SV, IV and USM content are comparable with those reported for other Moringa species (Somali et al. 1984; Tsaknis et al 1998; Lalas et al. 2003; Manzoor et al. 2007;). Moderate FFA content for Moringa oleifera oil in the present analysis was indicative of the good resistance of this oil to hydrolysis. SV value was in the range of mustard seed (170184) but lower than olive (184196), pumpkin (185-198), corn (maize) (187-195) and cottonseed (189-198) oils (Rossell 1991). USM content is within the range of almond $(0.40-1.00 \%)$, groundnut $(0.20$ $0.80 \%)$, palm (kernel) $(0.20$ $0.80 \%)$, soybean $(0.50-1.60 \%)$, and safflower $(0.30-1.50 \%)$ oils (Rossell 1991).
The oxidative state of the Moringa oleifera oils native to EGYPT as compared with the values available in the literature are shown in Table 2. The peroxide value (PV) (meq $\mathrm{kg}-1$ of oil) for $M$. oleifera ranged from 0.57 to 0.59 with different solvent-extraction was quite low compared to those reported for different Moringa varieties (Somali et al. 1984; Lalas et al. 2003; Manzoor et al. 2007). $P V$ measures the content of hydroperoxides in the oil and its low value indicates high resistance to oxidation. The specific extinctions at 232 and $270 \mathrm{~nm}$, with the values of 1.85 2.28 and $0.44-0.92$ respectively, reveal the oxidative deterioration and purity of the oils. The induction period (IP) (Rancimat method, $h$ at 120C), which was a characteristic of the oxidative stability of the oils and fats (Anwar et al. 2003), of the nondegummed (NDG) M. oleifera ranged from 40.4 to $54.1 \mathrm{~h}$ indicating moderate stability. After degumming (DG), the induction period (IP) of the oil decreased to 11.7-20.7 $\mathrm{h}$ which could be attributed to the degumming process. Some 
earlier reports also revealed a sizeable reduction in IP of the crude M. oleifera oils after degumming (Anwar et al. 2005; Anwar and Bhanger 2003; Anwar and Rashid 2007; Anwar et al. 2006; Lalas and Tsaknis 2002; Tsaknis et al. 1999; Tsaknis et al. 1998). High IP values of M. oleifera oil as exhibited in the present analysis compared with those of common vegetable oils (Anwar et al. 2003) indicate the presence of a high level of monoenoic fatty acids, particularly, C18:1, which was less prone to oxidation than polyenoics (Manzoor et al. 2007). High oxidative stability of seed fats of different Moringaceae species was also reported in the literature (Lalas et al. 2003; Manzoor et al. 2007; Tsaknis 1998).

The tocopherol profile $(\alpha-, \quad \gamma-$, and $\delta-)$ of Moringa oleifera, oil (non-degummed) is given in Table 3. The $\alpha-$ tocopherol content (126.1-127 $\mathrm{mg} \mathrm{kg-1),} \mathrm{which} \mathrm{has} \mathrm{the} \mathrm{greatest}$ vitamin E potency (Rossell 1991), was appreciably higher than palm kernel (44.0 mg kg-1) and coconut (17.0 mg kg-1) oils and fell in the range of soybean (9.0-352 mg kg-1), maize (23.0-573 mg kg-1), groundnut (49.0-304 mg kg-1) and palm (4.0-185 mg kg-1) oils (Rossell 1991). The $\gamma$-tocopherol content (ranging $\quad 61.8-62.2 \mathrm{mg} \quad \mathrm{kg}-1$ ) was also higher than those of coconut (14.0 mg kg-1) and sunflower (34.0 mg kg-1) oils (Rossell 1991). The $\delta$ tocopherol content (ranging 62.2 $-62.3 \mathrm{mg} \mathrm{kg}-1$ ), was found to be higher than coconut $(2.0 \mathrm{mg} \mathrm{kg}-$ 1), cottonseed (17.0 mg kg-1), groundnut (3.0-22.0 mg kg-1) and sunflower (7.0 mg kg-1) oils (Rossell 1991). The $\alpha-, \gamma-$, and $\delta$ - tocopherol contents in the present analysis of $\mathrm{M}$. oleifera oil were higher than those reported for M. concanensis oil (72.1, 9.26, $33.9 \mathrm{mg} \mathrm{kg} \mathrm{-1)}$ (Manzoor et al. 2007) and $M$. peregrina oil (145, 58.0 and 66.0 mg kg -1) (Tsaknis 1998). Such high tocopherol content would be expected to contribute good oxidative stability and protection to the M. oleifera oil during storage and processing.

The sterol composition of the Moringa oleifera oil for extracted fractions is shown in Table 4. $\beta$-sitosterol appeared to 
be the most predominant sterol in all the fractions followed by the following sterols: campesterol, stigmasterol and 5avenasterol. The sterol compositions of the most conventional edible oils varied from that of the investigated $\mathrm{M}$. oleifera oil (Rossell 1991). Variation in the phytosterol contents among the Moringa species of different regions and inter-cultivars have also been observed (Anwar and Rashid 2007).

Table 5 illustrates the fatty acid (FA) composition of the Moringa oleifera oil in Egypt. The oil was found to contain a high amount of oleic acid (C18:1) up to $74.4 \%$ with the predominant presence of the following saturated fatty acids: palmitic (C16:0), stearic (C18:0), arachidic (C20:0), and behenic (C22:0) acids. Higholeic oils are of great importance because of their superior stability and high nutritional value (Manzoor et al. 2007). Moringa oleifera oil of the indigenous-cultivar of EGYPT is a high-oleic acid and contains a high ratio fatty acids. Content of the major fatty acid (C18:1) was also higher than that of both $\mathrm{M}$. concanensis $(68.0 \%)$ (Manzoor et al. 2007) and M. peregrina oil (70.5\%) (Tsaknis 1998).

\section{CONCLUSIONS}

The expansion of the cultivation of $M$. oleifera oilseed in Egypt is an important project due to its high amount of oil with an average of $38.5 \%$, and to increased production of oil in Egypt to reduce the food gap for the production of more Egyptian oils.

\section{RECOMMENDATIONS}

Moringa plants are cultivated in Egyptian soils whereas the Upper Egypt soil was best than Delta Egypt soil. In addition, it is be advised to increase research and studies for this plant because of its nutritional and economic values, specially facing poverty and the shortage of protein source in Egypt.

\section{REFERENCES}
Abdulkarim SM; Long K; Lai OM; Muhammad SKS and Ghazali HM (2005): 
Some physico-chemical properties of Moringa oleifera seed oil extracted using solvent and aqueous enzymatic methods. Food Chem., 93, 253-263.

\section{Anwar F; Ashraf $M$ and} Bhanger MI (2005):

Interprovenance variation in the composition of Moringa oleifera oilseeds from Pakistan. J. Am. Oil Chem. Soc., 82, 45-51.

\section{Anwar F; Bhanger M and Kazi} T (2003):

Relationship between oxygen method values at varying temperatures for several oils and fats. $J$. Am. Oil Chem. Soc., 80, 151-155.

Anwar F and Bhanger MI (2003):

Analytical

characterization of

Moringa oleifera seed oil grown in temperate regions of Pakistan. $J$. Agric. Food Chem., 51, 6558-6563.
Anwar F; Zafar SN and Rashid U (2006):

Characterization of Moringa oleifera seed oil from drought and irrigated regions of Punjab, Pakistan. Grasas Aceites, 57, 160-168

\section{Anwar F and Rashid U (2007):}

Physio-chemical characteristics of Moringa oleifera seeds and seed oil from a wild provenance of Pakistan. Pak. J. Bot., 39, 1443-1453.

AOAC (1984):

Official methods of analysis of the Association of Official Analytical Chemists. (W. HORWITZ, ed.), Association of Official Analytical Chemists (AOAC), Washington, DC.

AOAC ( 1990):

Official Methods of Association of Official Analytical Chemists, Association of Official Analytical Chemists (AOAC), Virginia. 


\section{AOCS (1998):}

Official methods and recommended practices of the American Oil Chemists' Society, American Oil Chemists' Society (AOCS), Champaign, Illinois.

\section{Asresk (1995):}

The major constituents of the acetone fraction of Ethiopian Moringa stenopetala leaves. Mansoura Journal of Pharmacological Science 11(1): 55-64.

\section{Badgett B L (1964):}

Part I. The mustard oil glucoside from Moringa oleifera seed. Rice University $\mathrm{PhD}$ Thesis (student of Martin G. Ettlinger), Houston, TX, USA

\section{Bhuptawat H; Folkard GK and} Chaudhari S (2007):

Innovative physicochemical treatment of wastewater incorporating Moringa oleifera seed coagulant. J. Hazard. Mater., 142, 477-482.
Bharali R; Tabassum J and Azad M R H (2003):

Chemomodulatory effect of Moringa oleifera, Lam, on hepatic carcinogen metabolizing enzymes, antioxidant parameters and skin papillomagenesis in mice. Asian Pacific Journal of Cancer Prevention 4: 131-139

Dahot MU and Memon AR (1985):

Nutritive significance of oil extracted from Moringa oleifera seeds. J. Pharm. Univ Karachi, 3, 75-79.

Dahot M U (1998):

Antimicrobial activity of small protein of Moringa oleifera leaves. Journal of the Islamic Academy of Sciences 11(1): 6pp.

\section{Dietz M; Metzler R and Zarate C (1994):}

Food security in the village: the case of oilseed processing. Appropriate Tech., 20, 9-11. 
D'Souza J and Kulkarni AR (1993):

Comparative studies on nutritive values of tender foliage of seedlings and mature plants of Moringa oleifera Lam. Journal of Economic and Taxonomic Botany 17(2): 479-485.

\section{EL Ghdban EAE; Mahmud GF} and Carrie CH (2015):

Studies on The Cchemical Components of The Moringa oleifera Plant Grown Under Egyptian Conditions, Scientific J. Flowers \&Ornamental Plants,2(1):101-115

\section{Ibrahim SS; Ismail M; Samuel} G; Kamal E and EL Azhari T (1974):

Benseed: A potential oil source. Agric. Res. Rev., 52, 47-50.

Iupac (1987):

Standard methods for the analysis of oils, fats, and derivatives [International Union of Pure and Applied Chemistry (IUPAC). Applied Chemistry
Division. Commission on Oils, Fats, Derivatives]. (C. PAQUOT and A.

Lalas S and Tsaknis J (2002):

Characterization of Moringa oleifera seed oil variety "Periyakulam 1". J. Food Compos. Anal., 15, 65-77.

Lalas S; Tsaknis J and Sflomos K (2003):

Characterisation of Moringa stenopetala seed oil variety "Marigat" from island Kokwa. Eur. J. Lipid Sci. Technol., 105, 23-31.

Manzoor M; Anwar F; Iqbal T and Bhanger MI (2007):

Physico-chemical characterization of Moringa concanensis seeds and seed oil. J. Am. Oil Chem. Soc., 84, 413419.

\section{Pearson D; Egan H; Kirk RS and Sawyer R (1987): \\ Pearson's chemical analysis of foods,}


Longman Scientific \&

Technical, Harlow.

Pomeranz Y and Meloan CE (1994):

Food analysis: theory and practice, Chapman \& Hall, New York.

\section{Rossell JB (1991):}

Vegetable oils and fats. In Analysis of oilseeds, fats, and fatty foods, (J.B. ROSSELL and J.L.R. PRITCHARD, eds.) pp. 261-319, Elsevier Applied Science, London.

\section{Pritchard JLR (1991):}

Analysis and properties of oilseeds. In Analysis of oilseeds, fats, and fatty foods, (J.B. ROSSELL and J.L.R. PRITCHARD, eds.) pp. 80-98, Elsevier Applied Science, London.

\section{Snedecor GW and Cochran WG (1967):}

Statistical Methods. Iowa state Univ.Press, Iowa, USA.

\section{Siddhuraju $P$ and Becker $K$ (2003):}

Antioxidant Properties of Various Solvent Extracts of Total Phenolic Constituents from Three Different Agroclimatic Origins of Drumstick Tree (Moringa oleifera Lam.) Leaves. J. Agric. Food Chem., 51, 2144-2155.

\section{Somali M; Bajneid M and AL-} Fhaimani $S$ (1984):

Chemical composition and characteristics of Moringa peregrina seeds and seeds oil. J. Am. Oil Chem. Soc., 61, 85-86.

Tsaknis J (1998):

Characterization of Moringa peregrina Arabia seed oil. Grasas Aceites, 49, 170-176.

Tsaknis J; Lalas S; Gergis V; Dourtoglou $\mathrm{V}$ and Spiliotis $\mathrm{V}$ (1999):

Characterization of Moringa oleifera variety Mbololo seed oil of Kenya. J. Agric. Food Chem., 47, 4495-4499. 
Tsaknis J; Lalas S; Gergis V and Spiliotis V (1998):

A total characterisation of Moringa oleifera Malawi seed oil. Riv. Ital. Sost. Gras., 75, 21-27.
Vlahov G; Chepkwony PK and Ndalut PK (2002):

${ }^{13} \mathrm{C}$ NMR characterization of triacylglycerols of Moringa oleifera seed oil: an "oleic-vaccenic acid" oil. J. Agric. Food Chem., 50, 970-975.

Table 1: components (\%) of moringa oleifera seeds

\begin{tabular}{|c|c|c|c|c|c|}
\hline \multirow{2}{*}{ Location } & \multicolumn{5}{|c|}{ Composition (\%) } \\
\cline { 2 - 6 } & \multirow{2}{*}{ Oil } & Protein & Moisture & fiber & Ash \\
\hline (NS) & 40.2 & 31.8 & 7.10 & 6.88 & 6.5 \\
\hline (IS) & 38.4 & 31.7 & 6.8 & 6.75 & 6.48 \\
\hline (MA) & 37.5 & 30.9 & 6.90 & 6.82 & 6.45 \\
\hline
\end{tabular}


Table 2: physical and chemical characteristics of moringa oleifera oil

\begin{tabular}{|c|c|c|c|c|}
\hline & Unit & (NS) & (IS) & (MA) \\
\hline Density & $(24 \mathrm{C})\left(\mathrm{mg} \mathrm{mL}^{-1}\right)$ & 0.898 & 0.909 & 0.881 \\
\hline Refractive index & $(40 C)$ & 1.459 & 1.457 & 1.455 \\
\hline Color & (Red Unit) & 0.82 & 0.80 & 0.81 \\
\hline Color & (Yellow Unit) & 33.7 & 35.0 & 40.0 \\
\hline Viscosity & $(\mathrm{mPa} . \mathrm{s})$ & 56.5 & 45.1 & 57.0 \\
\hline Saponification value & (mg of $\mathrm{KOH} \mathrm{g}{ }^{-1}$ oil) & 180 & 188 & 178 \\
\hline Free Fatty Acid (FFA) & (\% as oleic acid) & 0.73 & 1.12 & 0.85 \\
\hline Iodine value & (g of per $100 \mathrm{~g}$ oil) & 68.9 & 65.6 & 66.8 \\
\hline Unsaponifiable matter & $(\%)$ & 0.77 & 0.75 & 0.73 \\
\hline Peroxide value & (meq of $\mathrm{O}_{2} \mathrm{~kg}^{-1}$ oil) & 0.57 & 0.58 & 0.59 \\
\hline
\end{tabular}

Table 3: tocopherol compositions ( $\mathrm{mg} \mathrm{kg}^{-1)}$ of moringa oleifera seed oil

\begin{tabular}{|c|c|c|c|}
\hline Tocopherol composition $\left(\mathrm{mg} \mathrm{kg}^{-1}\right)$ & (NS) & (IS) & (MA) \\
\hline$\alpha$-tocopherol & 127 & 126.1 & 126.5 \\
\hline$\gamma$-tocopherol & 62.2 & 62.1 & 61.8 \\
\hline$\delta$-tocopherol & 62.3 & 62.3 & 62.2 \\
\hline
\end{tabular}


Table 4: sterol compositions (\%) of moringa oleifera seed oil

\begin{tabular}{|c|c|c|c|}
\hline Sterol composition (\%) & (NS) & (IS) & (MA) \\
\hline Cholesterol & 0.13 & 0.10 & 0.13 \\
\hline Brassicasterol & 0.06 & 0.05 & 0.06 \\
\hline 24-Methylenecholesterol & 1.12 & 0.08 & 0.88 \\
\hline Campesterol & 16.7 & 15.3 & 15.1 \\
\hline Campestanol & 0.39 & 0.33 & 0.35 \\
\hline DELTA -7-Campestanol & 0.60 & ND & ND \\
\hline Stigmasterol & 18.0 & 23.1 & 16.9 \\
\hline Ergostadienol & 0.38 & 0.35 & 0.39 \\
\hline Clerosterol & 2.29 & 1.22 & 2.52 \\
\hline$\beta$-Sitosterol & 47.4 & 43.7 & 50.1 \\
\hline Stigmastanol & 0.86 & 0.64 & 0.86 \\
\hline DELTA -5-Avenasterol & 9.79 & 11.6 & 8.84 \\
\hline DELTA -7-Avenasterol & 1.04 & ND & 1.11 \\
\hline 28-isoavenasterol & 0.95 & 0.25 & 1.40 \\
\hline DELTA -7,14-stigmastanol & 0.60 & 0.85 & 0.44 \\
\hline
\end{tabular}


Table 5: fatty acid composition (\%) of moringa oleifera seed oil

\begin{tabular}{|c|c|c|c|}
\hline \multirow{2}{*}{$\begin{array}{l}\text { Fatty acid composition } \\
\qquad(\%)\end{array}$} & \multicolumn{3}{|c|}{ Location } \\
\hline & (NS) & (IS) & (MA) \\
\hline C8:0 & 0.03 & 0.03 & 0.03 \\
\hline C14:0 & 0.111 & 0.13 & 0.11 \\
\hline C16:0 & 6.16 & 6.46 & 6.04 \\
\hline C16:1 & 1.10 & 1.36 & 1.46 \\
\hline C17:0 & 0.09 & 0.08 & 0.09 \\
\hline C18:0 & 4.68 & 5.88 & 4.14 \\
\hline C18:1 & 74.2 & 71.2 & 73.6 \\
\hline C18:2 & 1.21 & 0.64 & 0.73 \\
\hline C18:3 & 0.24 & 0.18 & 0.22 \\
\hline C20:0 & 3.51 & 3.62 & 2.76 \\
\hline C20:1 & 1.61 & 2.22 & 2.40 \\
\hline C22:0 & 6.15 & 6.31 & 6.73 \\
\hline C22:1 & 0.14 & 0.12 & 0.14 \\
\hline C26:0 & 1.08 & 1.18 & 1.08 \\
\hline
\end{tabular}




\section{التقييم الكيميائي والغذائي لزيوت و بذور المورينجا

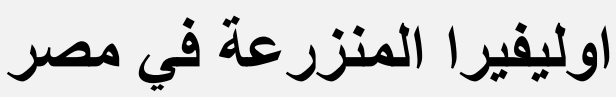

جميل فكري محمود 1 ،الموافي عبده الموافي الغضبان2 و محمد شحات سالم 3

$$
\begin{aligned}
& \text { 1) قسم الأغذية الوظيفية ـ المعهد القومي للتغذية الكندية - أوتوا }
\end{aligned}
$$

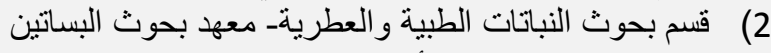

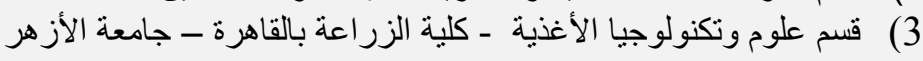

أجريت هذه الدراسة بقسم النباتات الطبية و العطرية ـ ـ معهد بحوث البساتين ـ مركز البحوث

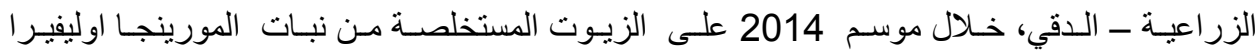

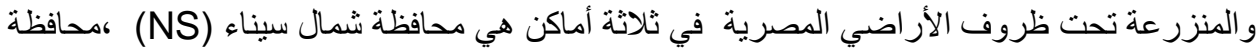

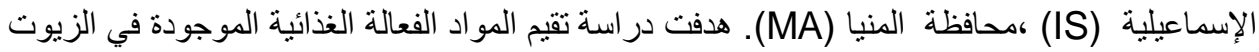

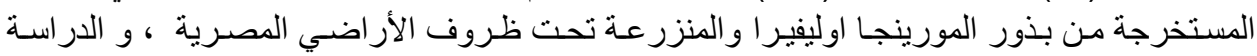

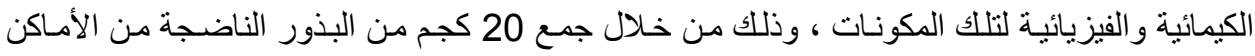

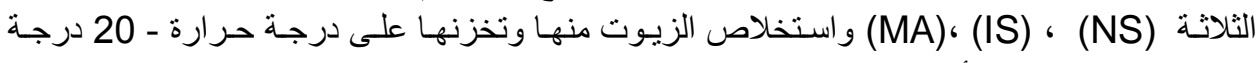

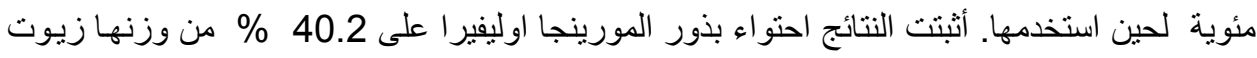

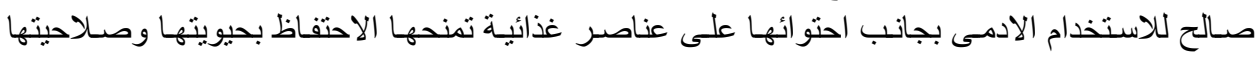

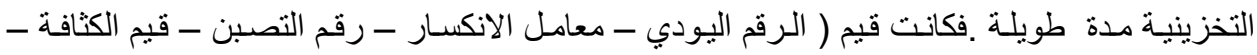

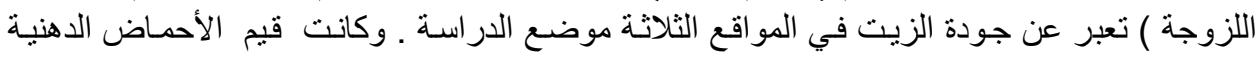

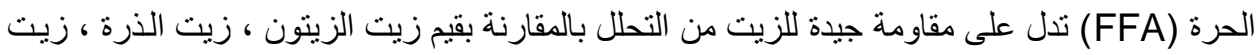

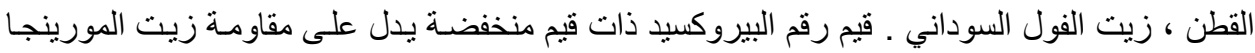

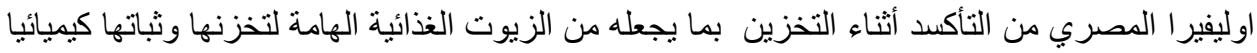

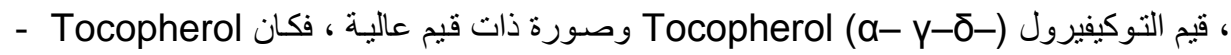

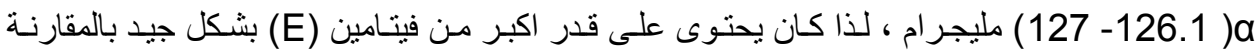

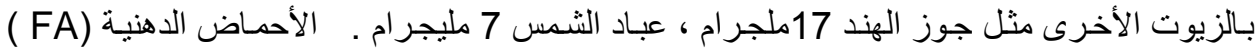

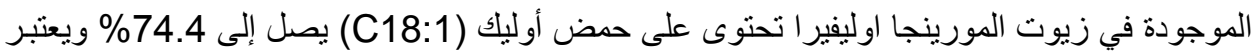

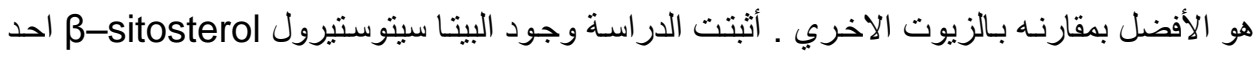

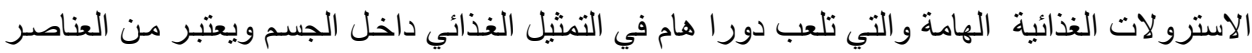

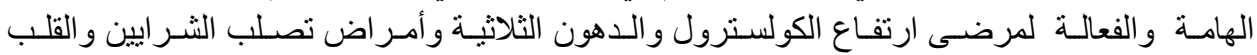
و أمر اض السمنة.

الكلمـات المغتاحيـة: المورينجـا الـوفير ا - زيـت المورينجـا الـوفير ا ـ الخصـائص الكيميائيـة للمورينجـا الوفيرا 